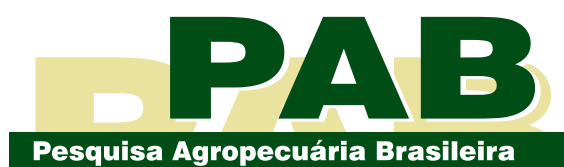

ISSN 1678-3921

Journal homepage: www.embrapa.br/pab

For manuscript submission and journal contents, access: www.scielo.br/pab
Edson Shigueaki Nomura ${ }^{(1 凶)}$ (D), Erval Rafael Damatto Junior ${ }^{(1)}$ (D), Miguel Angel Dita Rodriguez(2) (D), Edson Perito Amorim ${ }^{(3)}$ (D) and Alex Mesczezem Drominiski(4) (D)

(1) Agência Paulista de Tecnologia dos Agronegócios, Polo Regional Vale do Ribeira - Pariquera-Açu, BR 116, Km 460, Caixa Postal 122, CEP 11900-000 Registro, SP, Brazil.

E-mail: edson.nomura@sp.gov.br, erval.damatto@sp.gov.br

(2) Alliance of Bioversity International and International Center for Tropical Agriculture, Km 17, Recta Cali-Palmira, CP 763537 Cali, Colombia

E-mail:m.dita@cgiar.org

(3) Embrapa Mandioca e Fruticultura, Rua Embrapa, s/no, Caixa Postal 007, CEP 44380-000 Cruz das Almas, BA, Brazil. E-mail: edson.amorim@embrapa.br

(4) Universidade Estadual Paulista Júlio de Mesquita Filho, Campus de Registro, Rua Nelson Brihi Badur, $n \circ 0430$, Vila Tupy, CEP 11900-000 Registro, SP, Brazil. E-mail: mesczezen@gmail.com

$\bowtie$ Corresponding author

Received

November 13, 2020

Accepted

March 23, 2021

How to cite

NOMURA, E.S.; DAMATTO JUNIOR, E.R.; RODRIGUEZ, M.A.D.; AMORIM, E.P.; DROMINISKI, A.M. Vegetative and productive performance of plantain genotypes of the Terra subgroup. Pesquisa Agropecuária Brasileira, v.56, e02338, 2021. DOI: https://doi. org/10.1590/S1678-3921. pab2021.v56.02338.
Pomology/ Original Article

\section{Vegetative and productive performance of plantain genotypes of the Terra subgroup}

Abstract - The objective of this work was to evaluate the vegetative and productive performance of plantain (Musa spp.) genotypes of the Terra subgroup under the environmental conditions of the Ribeira Valley in the state of São Paulo, Brazil. The experimental design was randomized complete blocks, with 12 genotypes and four replicates. Two types of genotypes were evaluated: six of the French plantain type, using the Maranhão cultivar as a reference; and six of the Horn plantain type, using the D'Angola cultivar as a reference. The treatments were evaluated during two production cycles, based on the following variables: pseudostem height and diameter, number of active leaves, total number of suckers and of plant cycles, fruit fresh mass, fruit length and diameter, fresh mass of the second hand, number of hands and of fruits in the bunch, bunch mass of marketable fruits, and productivity. Of the Horn plantain genotypes, 78 and 88 presented a better vegetative and productive performance, smaller plants, a larger pseudostem diameter, and a higher productivity than the D'Angola cultivar. None of the French plantain genotypes was superior to the Maranhão cultivar in terms of productivity and fruit quality. However, genotypes $79,80,82$, and 84 present, as differential characteristics, a lower pseudostem height and a shorter total cycle, which could be explored to improve their productive potential.

Index terms: Musa, agronomic performance, cooking banana, plantain.

\section{Desempenho vegetativo e produtivo de genótipos de bananeira do subgrupo Terra}

Resumo - O objetivo deste trabalho foi avaliar o desempenho vegetativo e produtivo de genótipos de bananeira (Musa spp.) do subgrupo Terra nas condições edafoclimáticas do Vale do Ribeira, no estado de São Paulo, Brasil. O delineamento experimental foi em blocos ao acaso, com 12 genótipos e quatro repetições. Foram avaliados dois tipos de genótipos: seis do tipo Francês, tendo-se utilizado a cultivar Maranhão como referência; e seis do tipo Chifre, tendo-se utilizado a cultivar D'Angola como referência. Os tratamentos foram avaliados durante dois ciclos de produção, com base nas seguintes variáveis: altura e diâmetro do pseudocaule, número de folhas ativas, número total de filhos e ciclos de planta, massa fresca do fruto, comprimento e diâmetro do fruto, massa fresca da segunda penca, número de pencas e frutos no cacho, massa do cacho de frutos comerciáveis e produtividade. Dos genótipos do tipo Chifre, o 78 e 88 apresentaram melhor desempenho vegetativo e produtivo, plantas menores, e maiores diâmetro do pseudocaule e produtividade que a cultivar D'Angola. Nenhum dos genótipos do tipo Francês foi superior à cultivar Maranhão em termos de produtividade e qualidade dos frutos. No entanto, os genótipos 79, 80, 82 e 84 apresentam, como característica diferencial, menor altura do pseudocaule e menor ciclo total, o que pode ser explorado para melhorar o seu potencial produtivo.

Termos para indexação: Musa, desempenho agronômico, banana de cozinhar, plátanos. 


\section{Introduction}

Plantains, bananas from the plantain subgroup or cooking bananas (Musa spp., subgroup AAB and $\mathrm{AAAB}$ ), are one of the main starch crops in developing countries and, together with bananas for fresh consumption, are the most common fruits produced and consumed worldwide (Faria et al., 2010). In Brazil, plantain is cultivated mainly in the Northern and Northeastern regions, mostly under family farming conditions (Faria et al., 2010; Gonçalves, 2015), with an estimated production of 620 thousand tons, which corresponds to about $9 \%$ of the total volume of bananas in the country and $1.7 \%$ of the world's production of plantain (Albuquerque, 2016).

The main plantain cultivars in Brazil are: Maranhão, also called Comprida or Chifre de Boi, and Terrinha of the French plantain type; and D'Angola, also called Sete Pencas or Ringideira, of the Horn plantain type.

Part of the challenge for plantain production include pests and diseases. The plants are susceptible to the black sigatoka disease, reasonably resistant to yellow sigatoka, tolerant to Panama disease, moderately damaged by nematodes, and highly affected by the banana weevil (Cosmopolites sordidus Germar 1824). In addition, plantain usually have a shorter cycle than banana - the mother plant with a good production, the daughter with a lower production, and the granddaughter with a much lower production, mainly due to the high attack of the banana rhizome weevil (Faria et al., 2010; Amorim et al., 2013).

Despite its importance as a basic food crop in many regions and some efforts for natural germplasm selection by humans, not much attention has been given to plantain in Brazil. There is one known publication with recommendations for its cultivation (Albuquerque, 2016); however, more information is necessary to improve plantain crop management, which has been mostly based on that of the banana crop. For the genetic improvement of plantain genotypes, an agronomic assessment in diverse ecosystems and a market assessment for an adequate recommendation of new cultivars for use by farmers are required (Azevedo et al., 2010), as each genotype has a specific interaction with the environment, favoring variations regarding fruit productivity, precocity, and quality (Soto, 2011), which indicates the importance of evaluations in different edaphoclimatic conditions and production cycles.
The objective of this work was to evaluate the vegetative and productive performance of plantain genotypes of the Terra subgroup under the environmental conditions of the Ribeira Valley in the state of São Paulo, Brazil.

\section{Materials and Methods}

The experiment was carried out at an experimental farm located in the municipality of Pariquera-Açu, in

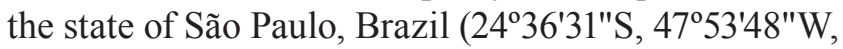
at $25 \mathrm{~m}$ above sea level). The climate of the region is of the Af type, rainy tropical, without a dry season, according to Köppen's classification. Climatic data on monthly precipitation and average monthly maximum and minimum temperatures for the study period from 2017-2019 are shown in Figure 1.

Before planting, soil samples, taken at a depth of 0 to $20 \mathrm{~cm}$, presented the following chemical attributes: $\mathrm{pH}\left(\mathrm{CaCl}_{2}\right) 5.0,28 \mathrm{~g} \mathrm{dm}^{-3}$ organic matter, $9.0 \mathrm{mg} \mathrm{dm}^{-3}$ $\mathrm{P}$ (resin), $2.5 \mathrm{mmol}_{\mathrm{c}} \mathrm{dm}^{-3} \mathrm{~K}, 31 \mathrm{mmol}_{\mathrm{c}} \mathrm{dm}^{-3} \mathrm{Ca}, 1.5$ $\mathrm{mmol}_{\mathrm{c}} \mathrm{dm}^{-3} \mathrm{Mg}, 34 \mathrm{mmol}_{\mathrm{c}} \mathrm{dm}^{-3} \mathrm{H}+\mathrm{Al}$, sum of bases of $48.5 \mathrm{mmol}_{\mathrm{c}} \mathrm{dm}^{-3}$, cation exchange capacity of 82.8 $\mathrm{mmol}_{\mathrm{c}} \mathrm{dm}^{-3}$, base saturation of $59 \%, 0.30 \mathrm{mg} \mathrm{dm}^{-3} \mathrm{~B}$, $0.2 \mathrm{mg} \mathrm{dm}^{-3} \mathrm{Cu}, 123 \mathrm{mg} \mathrm{dm}^{-3} \mathrm{Fe}, 1.6 \mathrm{mg} \mathrm{dm}^{-3} \mathrm{Mn}$, and $0.4 \mathrm{mg} \mathrm{dm}^{-3} \mathrm{Zn}$. Based on these soil fertility data and an expected productivity of $30 \mathrm{Mg} \mathrm{ha}^{-1}$, the rates of $\mathrm{N}$ and $\mathrm{K}$ were calculated and applied at planting and during plant growth, following the recommendations of Teixeira et al. (2014).

The experimental area was prepared two months before planting, with subsoiling and plowing, followed by the application and soil incorporation of dolomitic limestone in the total area, in the amount recommended according to the soil analysis, in order to increase base saturation to $70 \%$ and $\mathrm{Mg}$ content to above 9.0 $\mathrm{mmol}_{\mathrm{c}} \mathrm{dm}^{-3}$ (Raij et al., 1997). Phosphorus was applied in the planting furrow.

The treatments consisted of 12 plantain genotypes, identified with code numbers: $76,79,80,82,84$, and 90 of the French plantain type; and 77, 78, 81, 83, 86 and 88 of the Horn plantain type. Genotypes 76 and 86 are, respectively, the Maranhão (French plantain) and D'Angola (Horn plantain) cultivars, traditionally used as standards for comparisons.

The plantlets were produced by micropropagation, as described by Carvalho et al. (2012), in a laboratory and acclimated until they reached an adequate size for planting in the field, about $60 \mathrm{~cm}$ in height, and 
had six to seven leaves. Planting was carried out on December 19, 2016, at a spacing of $2.0 \times 2.5 \mathrm{~m}$, totaling 1,600 plants per hectare.

The plants of all treatments were subjected to the same cultural practices, including: thinning of plants, removal of senescent leaves, removal of the heart, and, when necessary, shoring of the plant (Teixeira et al., 2014). There was no hydric supplementation during the experiment. Black sigatoka was controlled by preventive applications of the fungicides recommended for the crop, at intervals defined by monitoring of the disease through the state of evolution method, adapted by Fouré (1988) and modified by Moraes et al. (2011).

The experimental design was randomized complete blocks, with 12 treatments and four replicates, and each experimental plot had four useful plants. The treatments were assessed in two production cycles, considering plant vegetative and productive performance.
Plant growth was evaluated by measuring: pseudostem height, from the soil level until the insertion of the last leaf; pseudostem diameter at $30 \mathrm{~cm}$ above ground level, using a pachymeter; number of active leaves (at least $50 \%$ of green area) at flowering and at bunch harvest; and number of suckers (taller or shorter than $30 \mathrm{~cm}$, and total) - after their quantification, all suckers, except the most developed one, were cut out. Vegetative development was considered the number of days from planting to flowering in the first cycle and the number of days from harvest in the first cycle to flowering in the second, whereas productive development was considered the number of days from flowering to bunch harvest. The total plant cycle (first cycle + second cycle) was also determined; the first cycle was considered the number of years from planting to harvest of the first bunch, and the second,

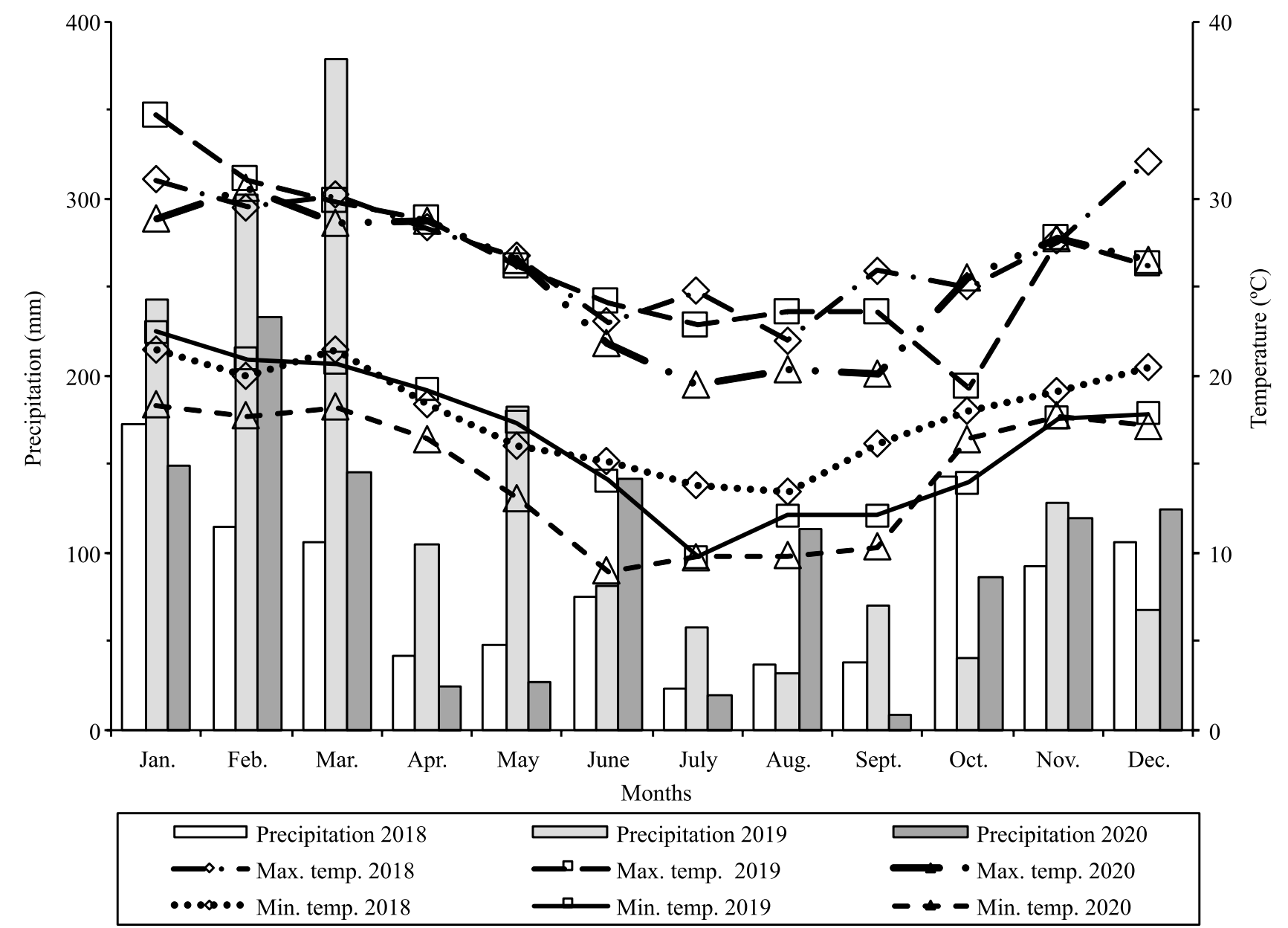

Figure 1. Precipitation and average monthly maximum (Max. temp.) and minimum (Min. temp.) temperatures between 2017-2019. Source: CIIAGRO (2021). 
the number of years from harvest of the bunch in the first cycle to harvest of the bunch in the second cycle.

The production of the genotypes in two production cycles was measured using the following variables: fresh mass of the bunch and stalk, determined on a digital scale and expressed in kilograms; fresh mass of marketable fruits per bunch, calculated as the difference between bunch and stalk masses; productivity, estimated from the fresh mass of marketable fruits, planting density, and total cycle ( $\mathrm{Mg} \mathrm{ha}^{-1}$ per year); number of hands and fruits in the bunch; fresh mass of and number of fruits in the second hand; and fresh mass, length, and diameter of the fruits.

The data were subjected to the analysis of variance using the F-test, and, when significant, means were compared by Tukey's test, at 5\% probability, using the SISVAR statistical package (Ferreira, 2011).

\section{Results and Discussion}

The French plantain genotypes presented significantly lower pseudostem heights over the two production cycles when compared with the Maranhão traditional cultivar (Table 1). Genotype 90 was the shortest one, whereas genotypes 82 and 84 were intermediate. The height obtained for the Maranhão cultivar was close to that reported by Coelho et al. (2013), but a little shorter than that observed by Faria et al. (2010) in the first production cycle. Among the studied Horn plantain genotypes, 78 and 88 were shorter than the D'Angola standard cultivar, as also found by Faria et al. (2010), Coelho et al. (2013), and Rodrigues Filho et al. (2020). In all types and genotypes studied, there was an increase in pseudostem height in the second cycle, as observed by Lima et al. (2005) and Lédo et al. (2008). The height of the pseudostem is one of the most important descriptors from a phytotechnical and improvement point of view, as it affects aspects related to planting density and crop management, directly interfering with production, facilitating or not harvest operation, and influencing the tipping or breaking of adult plants due to the action of the wind (Faria et al., 2010).

Table 1. Pseudostem height and diameter, as well as number of suckers in the first cycle, of French and Horn plantain (Musa spp.) genotypes under the environmental conditions of Ribeira Valley, located in the state of São Paulo, Brazil ${ }^{(1)}$.

\begin{tabular}{|c|c|c|c|c|c|c|c|c|c|}
\hline \multirow[t]{2}{*}{ Genotype } & \multicolumn{3}{|c|}{ Pseudostem height $(\mathrm{cm})$} & \multicolumn{3}{|c|}{ Pseudostem diameter $(\mathrm{cm})$} & \multicolumn{3}{|c|}{ Number of suckers in the $1^{\text {st }}$ cycle } \\
\hline & $1^{\text {st }}$ cycle & $2^{\text {nd }}$ cycle & Mean & $1^{\text {st }}$ cycle & $2^{\text {nd }}$ cycle & Mean & $<30 \mathrm{~cm}$ & $>30 \mathrm{~cm}$ & Total \\
\hline & \multicolumn{9}{|c|}{ French plantain } \\
\hline 90 & $210 \mathrm{a}$ & $227 \mathrm{a}$ & $218 \mathrm{a}$ & $17.9 \mathrm{~b}$ & $18.5 \mathrm{ab}$ & $18.2 \mathrm{bc}$ & $3.2 \mathrm{a}$ & $1.5 \mathrm{c}$ & $4.7 \mathrm{c}$ \\
\hline 82 & $303 \mathrm{aA}$ & $371 \mathrm{bB}$ & $337 b$ & $17.6 \mathrm{~b}$ & $21.5 \mathrm{ab}$ & $19.5 \mathrm{abc}$ & $3.5 \mathrm{a}$ & $5.1 \mathrm{ab}$ & $8.5 \mathrm{~b}$ \\
\hline 84 & $325 \mathrm{bcA}$ & $375 b B$ & $350 \mathrm{bc}$ & $18.4 \mathrm{ab}$ & $15.1 \mathrm{~b}$ & $16.8 \mathrm{c}$ & $2.7 \mathrm{a}$ & $7.9 \mathrm{a}$ & $10.6 \mathrm{a}$ \\
\hline 80 & $351 \mathrm{cA}$ & $395 \mathrm{bB}$ & $373 c$ & $20.9 \mathrm{ab}$ & $23.5 \mathrm{a}$ & $22.2 \mathrm{ab}$ & $2.0 \mathrm{a}$ & $3.7 \mathrm{bc}$ & $5.7 \mathrm{bc}$ \\
\hline 79 & $356 \mathrm{cA}$ & $397 \mathrm{bB}$ & $377 \mathrm{c}$ & $20.9 \mathrm{ab}$ & $23.9 \mathrm{a}$ & $22.4 \mathrm{ab}$ & $3.2 \mathrm{a}$ & $3.8 \mathrm{bc}$ & $7.0 \mathrm{bc}$ \\
\hline 'Maranhão' & $425 \mathrm{~d}$ & $447 \mathrm{c}$ & $436 \mathrm{~d}$ & $24.6 \mathrm{a}$ & $22.5 \mathrm{a}$ & $23.6 \mathrm{a}$ & $2.4 \mathrm{a}$ & $5.6 \mathrm{ab}$ & $8.0 \mathrm{~b}$ \\
\hline Mean & $328 \mathrm{~A}$ & 369B & & $20.0 \mathrm{~B}$ & $20.8 \mathrm{~A}$ & & 2.8 & 4.6 & 7.4 \\
\hline CV $1(\%)^{(2)}$ & & 6.0 & & & 14.1 & & 31.3 & 30.2 & 15.8 \\
\hline \multirow[t]{2}{*}{ CV $2(\%)^{(3)}$} & & 5.4 & & & 15.4 & & & & \\
\hline & \multicolumn{9}{|c|}{ Horn plantain } \\
\hline 88 & $225 \mathrm{aA}$ & $276 \mathrm{aB}$ & $251 \mathrm{a}$ & $19.1 \mathrm{a}$ & $23.2 \mathrm{a}$ & $21.2 \mathrm{a}$ & $3.2 \mathrm{a}$ & $2.5 \mathrm{a}$ & $5.7 \mathrm{a}$ \\
\hline 78 & $225 \mathrm{aA}$ & $279 \mathrm{aB}$ & $252 \mathrm{a}$ & $19.4 \mathrm{aB}$ & $23.4 \mathrm{aA}$ & $21.4 \mathrm{a}$ & $2.7 \mathrm{a}$ & $2.4 \mathrm{a}$ & $5.0 \mathrm{a}$ \\
\hline 81 & $306 \mathrm{bA}$ & $386 \mathrm{aB}$ & $346 b$ & $17.8 \mathrm{aB}$ & $20.9 \mathrm{aA}$ & 19.3a & $3.8 \mathrm{a}$ & $2.9 \mathrm{a}$ & $6.7 \mathrm{a}$ \\
\hline 77 & $309 \mathrm{bA}$ & $363 \mathrm{aB}$ & $336 b$ & $19.4 \mathrm{aB}$ & $22.3 \mathrm{aA}$ & $20.8 \mathrm{a}$ & $4.7 \mathrm{a}$ & $2.6 \mathrm{a}$ & $7.2 \mathrm{a}$ \\
\hline 'D’Angola' & $311 \mathrm{bA}$ & $386 \mathrm{aB}$ & $349 b$ & $19.2 \mathrm{aB}$ & $22.4 \mathrm{aA}$ & $20.8 \mathrm{a}$ & $2.7 \mathrm{a}$ & $3.4 \mathrm{a}$ & $6.1 \mathrm{a}$ \\
\hline 83 & $317 \mathrm{bA}$ & $403 \mathrm{aB}$ & $360 \mathrm{~b}$ & $18.9 \mathrm{aB}$ & $23.5 \mathrm{aA}$ & $21.2 \mathrm{a}$ & $2.8 \mathrm{a}$ & $3.6 \mathrm{a}$ & $6.4 \mathrm{a}$ \\
\hline Mean & $282 \mathrm{~A}$ & $349 B$ & & $19.0 \mathrm{~B}$ & $22.6 \mathrm{~A}$ & & 3.3 & 2.9 & 6.2 \\
\hline CV $1(\%)^{(2)}$ & & 7.1 & & & 9.5 & & 26.9 & 27.4 & 16.1 \\
\hline CV $2(\%)^{(3)}$ & & 5.4 & & & 5.1 & & & & \\
\hline
\end{tabular}

${ }^{(1)}$ Means followed by different letters, lowercase in the columns and uppercase in the lines, differ by Tukey's test, at $5 \%$ probability. ${ }^{(2)}$ Coefficient of variation for genotypes. ${ }^{(3)}$ Coefficient of variation for cycles. 
The diameter of the pseudostem of the French plantains was smaller for genotypes 90 and 84 (Table 1). This is not interesting from an agronomic point of view because of the lower resistance to pseudostem breaking and higher vulnerability to root problems caused by the attack of nematodes and the banana weevil (Tripathi et al., 2015). The other genotypes presented larger and suitable diameters for the cultivation of plantain. Faria et al. (2010) and Coelho et al. (2013) found pseudostem diameters of 37.2 and $31.0 \mathrm{~cm}$, respectively, for cultivar Maranhão, which are values greater than those obtained in the present study.

No significant differences were observed for pseudostem diameter between the Horn plantain genotypes. There were only differences between production cycles, with higher values in the second cycle for all genotypes, except for 88. Faria et al. (2010), Coelho et al. (2013), and Rodrigues Filho et al. (2020) found pseudostem diameters between 23 and $27 \mathrm{~cm}$ for cultivar D'Angola, greater than that obtained in the present work for the same cultivar.

The height and diameter of the pseudostem are important parameters in the selection of banana cultivars, being related to plant vigor, ease of harvesting the bunch, and resistance to breaking and/ or tipping of adult plants, with fewer risks of losses in production (Faria et al., 2010). Genotypes 79 and 80 of the French plantain type and 78 and 88 of Horn plantain stood out for presenting a pseudostem with a shorter height and larger diameter. This is interesting since pseudostem diameter values correlate positively with a lower susceptibility to tipping (Borges et al., 2011). This information and plantain susceptibility to banana weevil (Moreira, 1999) lead breeding programs to look for genotypes with a pseudostem with a lower height and larger diameter, reducing risks of production losses.

Among French plantain, genotype 84 produced the largest number of suckers in the first production cycle. However, no significant difference was observed between the Horn plantain genotypes (Table 1). In both types of plantain, the mother plant did not inhibit the production and development of the suckers, which usually occurs with cultivars Maranhão and D'Angola, delaying the production of subsequent cycles (Soto, 2011).

Among the French plantain type, genotype 90 presented a shorter cycle for flowering and production when compared with the Maranhão cultivar (Table 2),

Table 2. Average values for the periods from planting to flowering in the first cycle, from harvest in the first cycle to flowering in the second cycle (NYPF), and for the total cycle, expressed in number of years, and from flowering to harvest (NDFH), expressed in number of days, for French and Horn plantain (Musa spp.) genotypes under the environmental conditions of Ribeira Valley, located in the state of São Paulo, Brazil( ${ }^{(1)}$.

\begin{tabular}{|c|c|c|c|c|c|c|c|c|c|}
\hline \multirow[t]{2}{*}{ Genotype } & \multicolumn{2}{|c|}{ NYPF (years) } & \multirow[t]{2}{*}{ Mean } & \multicolumn{2}{|c|}{ NDFH (days) } & \multirow[t]{2}{*}{ Mean } & \multicolumn{2}{|c|}{ Total cycle (years) } & \multirow[t]{2}{*}{ Mean } \\
\hline & $1^{\text {st }}$ cycle & $2^{\text {nd }}$ cycle & & $1^{\text {st }}$ cycle & $2^{\text {nd }}$ cycle & & $1^{\text {st }}$ cycle & $2^{\text {nd }}$ cycle & \\
\hline & \multicolumn{9}{|c|}{ French plantain } \\
\hline 90 & $0.98 \mathrm{a}$ & $0.98 \mathrm{a}$ & $0.98 \mathrm{a}$ & $86 a b$ & $88 \mathrm{a}$ & $87 \mathrm{a}$ & $1.23 \mathrm{aB}$ & $1.08 \mathrm{aA}$ & $1.15 \mathrm{a}$ \\
\hline 82 & $1.05 \mathrm{abB}$ & $0.93 \mathrm{aA}$ & $0.99 \mathrm{ab}$ & $102 \mathrm{ab}$ & $92 \mathrm{a}$ & $97 \mathrm{ab}$ & $1.35 \mathrm{aB}$ & $1.05 \mathrm{aA}$ & $1.20 \mathrm{a}$ \\
\hline 84 & $1.05 \mathrm{ab}$ & $0.98 \mathrm{a}$ & $1.01 \mathrm{ab}$ & $95 \mathrm{ab}$ & $95 \mathrm{a}$ & $95 \mathrm{ab}$ & $1.35 \mathrm{aB}$ & $1.08 \mathrm{aA}$ & $1.21 \mathrm{a}$ \\
\hline 80 & $1.10 \mathrm{bB}$ & $1.00 \mathrm{aA}$ & $1.05 \mathrm{ab}$ & $73 \mathrm{aA}$ & $99 \mathrm{aB}$ & $86 a$ & $1.33 \mathrm{aB}$ & $1.15 \mathrm{aA}$ & $1.24 \mathrm{a}$ \\
\hline 79 & $1.13 \mathrm{bB}$ & $1.03 \mathrm{aA}$ & $1.08 \mathrm{~b}$ & $88 \mathrm{ab}$ & $90 \mathrm{a}$ & $89 \mathrm{a}$ & $1.35 \mathrm{aB}$ & $1.18 \mathrm{abA}$ & $1.26 \mathrm{a}$ \\
\hline 'Maranhão' & $1.33 \mathrm{cB}$ & $1.15 \mathrm{bA}$ & $1.24 \mathrm{c}$ & $119 \mathrm{~b}$ & $110 \mathrm{a}$ & $115 \mathrm{~b}$ & $1.68 \mathrm{bB}$ & $1.30 \mathrm{bA}$ & $1.49 \mathrm{~b}$ \\
\hline Mean & $1.10 \mathrm{bB}$ & $1.01 \mathrm{~A}$ & & $94 \mathrm{~A}$ & $96 \mathrm{~A}$ & & $1.38 \mathrm{~B}$ & 1.14 & \\
\hline \multirow[t]{2}{*}{ CV $1(\%)^{(2) / C V} 2(\%)^{(3)}$} & & $5.7 / 5.1$ & & & $13.5 / 16.7$ & & & $6.7 / 4.6$ & \\
\hline & \multicolumn{9}{|c|}{ Horn plantain } \\
\hline 88 & $1.00 \mathrm{a}$ & $0.90 \mathrm{a}$ & $0.95 \mathrm{a}$ & $83 a$ & $87 a$ & $85 \mathrm{a}$ & $1.20 \mathrm{aB}$ & $1.03 \mathrm{aA}$ & $1.11 \mathrm{a}$ \\
\hline 78 & $0.98 \mathrm{a}$ & $0.88 \mathrm{a}$ & $0.93 a$ & $80 \mathrm{a}$ & $84 a$ & $82 \mathrm{a}$ & $1.20 \mathrm{Ab}$ & $1.00 \mathrm{Aa}$ & $1.10 \mathrm{a}$ \\
\hline 81 & $0.95 \mathrm{a}$ & $0.93 a$ & $0.94 \mathrm{a}$ & $88 \mathrm{a}$ & $89 \mathrm{a}$ & $89 \mathrm{a}$ & $1.20 \mathrm{aB}$ & $1.03 \mathrm{aA}$ & $1.11 \mathrm{a}$ \\
\hline 77 & $0.98 \mathrm{a}$ & $0.95 \mathrm{a}$ & $0.96 \mathrm{a}$ & $85 \mathrm{a}$ & $73 a$ & $79 \mathrm{a}$ & $1.20 \mathrm{aB}$ & $1.03 \mathrm{aA}$ & $1.11 \mathrm{a}$ \\
\hline 'D'Angola' & $1.00 \mathrm{aB}$ & $0.83 \mathrm{aA}$ & $0.91 \mathrm{a}$ & $78 \mathrm{a}$ & $74 a$ & $76 \mathrm{a}$ & $1.23 \mathrm{aB}$ & $1.00 \mathrm{aA}$ & $1.11 \mathrm{a}$ \\
\hline 83 & $1.03 \mathrm{a}$ & $0.93 \mathrm{a}$ & $0.98 \mathrm{a}$ & $76 \mathrm{a}$ & $82 \mathrm{a}$ & $79 \mathrm{a}$ & $1.20 \mathrm{aB}$ & $1.03 \mathrm{aA}$ & $1.11 \mathrm{a}$ \\
\hline Mean & $0.98 \mathrm{~B}$ & $0.90 \mathrm{~A}$ & & $81 \mathrm{~A}$ & $82 \mathrm{~A}$ & & $1.20 \mathrm{~B}$ & $1.02 \mathrm{~A}$ & \\
\hline CV $1(\%)^{(2) / C V} 2(\%)^{(3)}$ & & $10.6 / 7.5$ & & & $14.2 / 12.0$ & & & $4.2 / 2.9$ & \\
\hline
\end{tabular}

${ }^{(1)}$ Means followed by different letters, lowercase in the columns and uppercase in the lines, differ by Tukey' test, at $5 \%$ probability. ${ }^{\left({ }^{2}\right)}$ Coefficient of variation for genotypes. ${ }^{(3)}$ Coefficient of variation for cycles. 
corroborating the results of Faria et al. (2010) and Coelho et al. (2013). Among the Horn plantain genotypes, no significant differences were observed for the vegetative, productive, and total cycles (Table 2). The vegetative, productive, and total cycles of cultivar D'Angola were of 295 (0.81 year), 56 (0.15 year), and 365 (1.0 year) days, respectively, when grown in the municipality of Guanambi, in the southwest of the state of Bahia, Brazil (Faria et al., 2010); these cycles are shorter than those obtained for the genotypes of Horn plantain evaluated in the present work. This is mainly due to differences in cultivation and environmental conditions, since the Ribeira Valley region has a period with low temperatures and less rainfall (Figure 1) that reduces the growth rate of plantain and lengthens its production cycle. A shorter cycle is a major goal in the genetic improvement of plantain, as it represents the expectation of a faster return on the initial investment (Faria et al., 2010). A shorter cycle also reduces the risk of the incidence of pests and diseases, resulting in a lower use of pesticides. In this sense, all genotypes of the French type were earlier than the traditionally cultivated cultivar, Maranhão, even in the subtropical climatic conditions of the study region. For the Horn plantain type, all genotypes behaved equally in the vegetative, productive, and total cycles, with no advantage in relation to cultivar D'Angola, traditionally grown in Brazil.

The number of active leaves at flowering for the French plantain type was higher in cultivar Maranhão only compared with genotype 90 , regardless of the production cycle (Table 3). In Horn plantain, there was no significant difference between genotypes regarding the number of active leaves at flowering. The number of leaves observed in the present study for all genotypes was much lower than those reported by Faria et al. (2010) for cultivars Maranhão and D'Angola. However, all genotypes had enough leaves for an adequate development of the bunch, since, according to González et al. (2012), at least six functional leaves are needed in the banana flowering phase.

Considering the average of the two cycles, the number of active leaves at harvest was higher in the French plantain genotypes 79, 80, and cultivar Maranhão, while there was no significant difference between the Horn

Table 3. Number of leaves at flowering and at harvest of French and Horn plantain (Musa spp.) genotypes under the environmental conditions of Ribeira Valley, located in the state of São Paulo, Brazil ${ }^{(1)}$.

\begin{tabular}{|c|c|c|c|c|c|c|}
\hline \multirow[t]{2}{*}{ Genotype } & \multicolumn{2}{|c|}{ Number of leaves at flowering } & \multirow[t]{2}{*}{ Mean } & \multicolumn{2}{|c|}{ Number of leaves at harvest } & \multirow[t]{2}{*}{ Mean } \\
\hline & $1^{\text {st }}$ cycle & $2^{\text {nd }}$ cycle & & $1^{\text {st }}$ cycle & $2^{\text {nd }}$ cycle & \\
\hline & \multicolumn{6}{|c|}{ French plantain } \\
\hline 79 & $12.1 \mathrm{aA}$ & $10.2 \mathrm{abB}$ & $11.1 \mathrm{ab}$ & $6.3 \mathrm{a}$ & $5.2 \mathrm{a}$ & $5.7 \mathrm{a}$ \\
\hline 82 & $11.0 \mathrm{ab}$ & $10.4 \mathrm{ab}$ & $10.7 \mathrm{ab}$ & $3.8 \mathrm{~b}$ & $3.1 b$ & $3.5 b$ \\
\hline 84 & 11.9abA & $10.0 \mathrm{abB}$ & $10.9 \mathrm{ab}$ & $4.2 b$ & $3.3 b$ & $3.7 b$ \\
\hline 80 & 11.8abA & $10.5 \mathrm{abB}$ & $11.1 \mathrm{ab}$ & $6.2 \mathrm{a}$ & $5.4 \mathrm{a}$ & $5.8 \mathrm{a}$ \\
\hline 'Maranhão' & $11.5 \mathrm{ab}$ & $11.3 \mathrm{a}$ & $11.4 \mathrm{a}$ & $5.9 \mathrm{a}$ & $5.3 \mathrm{a}$ & $5.6 \mathrm{a}$ \\
\hline 90 & $10.4 \mathrm{bB}$ & $9.4 \mathrm{bA}$ & $9.9 \mathrm{~b}$ & $3.6 \mathrm{~b}$ & $2.8 \mathrm{~b}$ & $3.2 \mathrm{~b}$ \\
\hline Mean & $11.4 \mathrm{~A}$ & $10.3 \mathrm{~B}$ & & $5.0 \mathrm{~A}$ & $4.2 \mathrm{~B}$ & \\
\hline $\operatorname{CV} 1(\%)^{(2)}$ & & 8.0 & & & 24.3 & \\
\hline \multirow[t]{2}{*}{ CV $2(\%)^{(3)}$} & & 5.9 & & & 16,7 & \\
\hline & \multicolumn{6}{|c|}{ Horn plantain } \\
\hline 78 & $11.3 \mathrm{a}$ & $11.2 \mathrm{a}$ & $11.3 \mathrm{a}$ & $5.9 \mathrm{a}$ & $6.5 \mathrm{a}$ & $6.2 \mathrm{a}$ \\
\hline 83 & $11.7 \mathrm{a}$ & $11.1 \mathrm{ab}$ & $11.4 \mathrm{a}$ & $6.9 \mathrm{aA}$ & $5.2 \mathrm{aB}$ & $6.1 \mathrm{a}$ \\
\hline 88 & $11.1 \mathrm{a}$ & $10.5 \mathrm{abc}$ & $10.8 \mathrm{a}$ & $6.4 \mathrm{a}$ & $5.9 \mathrm{a}$ & $6.1 \mathrm{a}$ \\
\hline 'D'Angola' & $11.5 \mathrm{aA}$ & $10.4 \mathrm{abcB}$ & $10.9 \mathrm{a}$ & $6.2 \mathrm{a}$ & $5.0 \mathrm{a}$ & $5.3 \mathrm{a}$ \\
\hline 77 & $11.7 \mathrm{aA}$ & $10.0 \mathrm{bcB}$ & $10.9 \mathrm{a}$ & $5.7 \mathrm{a}$ & $4.9 \mathrm{a}$ & $5.3 \mathrm{a}$ \\
\hline 81 & $11.2 \mathrm{aA}$ & $9.6 \mathrm{cB}$ & $10.4 \mathrm{a}$ & $5.8 \mathrm{a}$ & $5.9 \mathrm{a}$ & $5.9 \mathrm{a}$ \\
\hline Mean & $11.4 \mathrm{~A}$ & $10.5 \mathrm{~B}$ & & $6.1 \mathrm{~A}$ & $5.6 \mathrm{~B}$ & \\
\hline CV $1(\%)^{(2)}$ & & 7.1 & & & 16.6 & \\
\hline CV $2(\%)^{(3)}$ & & 4.7 & & & 12.7 & \\
\hline
\end{tabular}

${ }^{(1)}$ Means followed by different letters, lowercase in the columns and uppercase in the lines, differ by Tukey's test, at $5 \%$ probability. ${ }^{(2)}$ Coefficient of variation for genotypes. ${ }^{(3)}$ Coefficient of variation for cycles. 
plantain genotypes (Table 3). The number of leaves at harvest was also lower than that observed by Faria et al. (2010) for cultivars Maranhão and D’Angola, which showed normal fruit development until harvest, possibly due to the lower inoculum pressure of the black sigatoka fungus in the study site, located in the municipality of Guanambi, in the state of Bahia. The reduction in the number of leaves from flowering to the harvest of the bunch is mainly attributed to the translocation of photoassimilates to fill the fruits, which become the plant's main drain, as well as to the natural senescence of the leaves and to the intensity of the attack of black sigatoka and the tolerance of the genotype to the disease (Silva et al., 2006).

Among the French plantain type, cultivar Maranhão presented the highest values for fresh mass of marketable fruits per bunch and productivity (Table 4). However, there was no statistical difference in relation to genotypes 79 and 80 for fresh mass of marketable fruits per bunch in the first cycle and to genotype 82 for productivity in the second cycle. The longer cycle and the greater plant vegetative vigor of the
Maranhão cultivar resulted, as expected, in superior production results.

Among the Horn plantain genotypes, 88 showed a productive performance superior to that of the D'Angola traditional cultivar in both cycles and for both mass of marketable fruits per bunch and crop productivity (Table 4). The productivity of the D'Angola cultivar was inferior to the averages of $11.9,12.9$, and $22.6 \mathrm{Mg} \mathrm{ha}^{-1}$ per year, respectively, reported by Faria et al. (2010), Coelho et al. (2013), and Cavalcante et al. (2014). The performance of genotypes 78 and 88 was expressive, and, as their plants were smaller (Table 1), it is possible to obtain a higher productivity by increasing their planting density.

According to Nomura et al. (2013), the evaluation of the productive potential of banana and plantain should not be restricted to the data of the first cycle, as increased values tend to be obtained in subsequent cycles. However, this was not observed for most of the production variables in the present work, except for productivity of genotypes 78 and 88 and for fresh mass of marketable fruits and fresh mass of the second

Table 4. Fresh mass of marketable fruits per bunch, productivity, and number of hands of French and Horn plantain (Musa spp.) genotypes under the environmental conditions of Ribeira Valley, located in the state of São Paulo, Brazil ${ }^{(1)}$.

\begin{tabular}{|c|c|c|c|c|c|c|c|c|c|}
\hline \multirow[t]{2}{*}{ Genotype } & \multicolumn{3}{|c|}{ Fresh mass of marketable fruits $(\mathrm{kg})$} & \multicolumn{3}{|c|}{ Productivity $\left(\mathrm{Mg} \mathrm{ha}^{-1}\right.$ per year) } & \multicolumn{3}{|c|}{ Number of hands } \\
\hline & $1^{\text {st }}$ cycle & $2^{\text {nd }}$ cycle & Mean & $1^{\text {st }}$ cycle & $2^{\text {nd }}$ cycle & Mean & $1^{\text {st }}$ cycle & $2^{\text {nd }}$ cycle & Mean \\
\hline & \multicolumn{9}{|c|}{ French plantain } \\
\hline 'Maranhão' & $21.1 \mathrm{a}$ & $20.6 \mathrm{a}$ & $20.9 \mathrm{a}$ & $20.8 \mathrm{a}$ & $25.2 \mathrm{a}$ & $23.1 \mathrm{a}$ & $7.7 \mathrm{a}$ & $7.4 \mathrm{ab}$ & $7.5 \mathrm{a}$ \\
\hline 80 & $14.9 \mathrm{ab}$ & $10.8 \mathrm{~b}$ & $12.8 \mathrm{~b}$ & $18.3 \mathrm{a}$ & $15.0 \mathrm{~b}$ & $16.7 \mathrm{~b}$ & $6.6 \mathrm{ab}$ & $7.8 \mathrm{a}$ & $7.2 \mathrm{a}$ \\
\hline 79 & $14.7 \mathrm{ab}$ & $11.8 \mathrm{~b}$ & $13.3 b$ & $17.5 \mathrm{a}$ & $16.1 \mathrm{~b}$ & $16.8 \mathrm{~b}$ & $6.7 \mathrm{ab}$ & $7.4 \mathrm{ab}$ & $7.1 \mathrm{ab}$ \\
\hline 84 & $13.6 \mathrm{~b}$ & $11.0 \mathrm{~b}$ & $12.3 b$ & $16.6 \mathrm{a}$ & $16.2 b$ & $16.4 \mathrm{~b}$ & $6.4 \mathrm{ab}$ & $6.8 \mathrm{abc}$ & $6.6 \mathrm{ab}$ \\
\hline 82 & $13.3 b$ & $12.9 \mathrm{~b}$ & $13.1 \mathrm{~b}$ & $15.9 \mathrm{a}$ & $19.5 \mathrm{ab}$ & $17.7 \mathrm{ab}$ & $6.1 \mathrm{bc}$ & $6.0 \mathrm{bc}$ & $6.1 \mathrm{ab}$ \\
\hline 90 & $11.5 \mathrm{~b}$ & $8.5 \mathrm{~b}$ & $10.0 \mathrm{~b}$ & $15.2 \mathrm{a}$ & $12.8 \mathrm{~b}$ & $14.0 \mathrm{~b}$ & $5.7 \mathrm{c}$ & $5.6 \mathrm{c}$ & $5.6 \mathrm{~b}$ \\
\hline Mean & $14.9 \mathrm{~A}$ & $12.6 \mathrm{~B}$ & & 17.4 & 17.5 & & $6.5 \mathrm{~A}$ & $6.8 \mathrm{~A}$ & \\
\hline CV $1(\%)^{(2)}$ & \multicolumn{2}{|c|}{22.7} & \multicolumn{4}{|c|}{24.6} & \multicolumn{3}{|c|}{13.8} \\
\hline \multirow[t]{2}{*}{ CV $2(\%)^{(3)}$} & \multicolumn{2}{|c|}{21.5} & \multicolumn{4}{|c|}{22.1} & \multicolumn{3}{|c|}{9.5} \\
\hline & \multicolumn{9}{|c|}{ Horn plantain } \\
\hline 88 & $8.9 \mathrm{aB}$ & $11.5 \mathrm{a}$ & $10.2 \mathrm{a}$ & $12.1 \mathrm{a}$ & $18.3 \mathrm{a}$ & $15.2 \mathrm{a}$ & $7.0 \mathrm{a}$ & $7.4 \mathrm{a}$ & $7.2 \mathrm{a}$ \\
\hline 78 & $8.4 \mathrm{ab}$ & $9.3 b$ & $8.9 \mathrm{ab}$ & $11.4 \mathrm{ab}$ & $14.7 \mathrm{~b}$ & $13.1 \mathrm{ab}$ & $6.9 \mathrm{a}$ & $6.9 \mathrm{ab}$ & $6.6 \mathrm{ab}$ \\
\hline 'D’ Angola' & $8.0 \mathrm{ab}$ & $7.1 \mathrm{c}$ & $7.5 \mathrm{bc}$ & $10.5 \mathrm{ab}$ & $11.0 \mathrm{c}$ & $10.8 \mathrm{bc}$ & $6.2 \mathrm{a}$ & $5.8 \mathrm{ab}$ & $6.0 \mathrm{bc}$ \\
\hline 83 & 7.1 ab & $7.2 \mathrm{c}$ & $7.2 \mathrm{bc}$ & $9.4 \mathrm{ab}$ & $11.4 \mathrm{c}$ & $10.4 \mathrm{bc}$ & $5.8 \mathrm{a}$ & $5.3 b$ & $5.5 \mathrm{c}$ \\
\hline 81 & $6.5 b$ & $7.0 \mathrm{c}$ & $6.7 \mathrm{c}$ & $8.7 \mathrm{~b}$ & $11.1 \mathrm{c}$ & $9.9 \mathrm{bc}$ & $5.6 \mathrm{a}$ & $5.3 b$ & $5.4 \mathrm{c}$ \\
\hline 77 & $6.8 \mathrm{~b}$ & $6.0 \mathrm{c}$ & $6.4 \mathrm{c}$ & $9.1 \mathrm{ab}$ & $9.3 \mathrm{c}$ & $9.2 \mathrm{c}$ & $5.9 \mathrm{a}$ & $5.3 \mathrm{~b}$ & $5.6 \mathrm{c}$ \\
\hline Mean & $7.6 \mathrm{~A}$ & $8.0 \mathrm{~A}$ & & $10.2 \mathrm{~B}$ & $12.6 \mathrm{~A}$ & & $6.2 \mathrm{~A}$ & $6.0 \mathrm{~A}$ & \\
\hline CV $1(\%)^{(2)}$ & & 15.4 & & & 19.0 & & & 12.0 & \\
\hline $\operatorname{CV} 2(\%)^{(3)}$ & & 11.8 & & & 12.7 & & & 12.4 & \\
\hline
\end{tabular}

${ }^{(1)}$ Means followed by different letters, lowercase in the columns and uppercase in the lines, differ by Tukey's test, at $5 \%$ probability. ${ }^{(2)}$ Coefficient of variation for genotypes. ${ }^{(3)}$ Coefficient of variation for cycles. 
hand of genotype 88. A major factor that contributes to a lower second cycle performance is the high susceptibility of the plants to the rhizome weevil, which is a common characteristic of plantain genotypes. This shows how the lack of studies and information on these cultivars leads to management practices without adequate techniques (Lins et al., 2013).

Another productive characteristic, number of hands, was also higher in cultivar Maranhão of the French plantain type, considering the average of the two productive cycles (Table 4); however, the obtained results were below those of Faria et al. (2010) and Coelho et al. (2013). Among the Horn plantain genotypes, 88 was the one that had the highest number of hands, being superior to cultivar D'Angola, whose results were similar to those reported by Faria et al. (2010) and Coelho et al. (2013).

Among the French plantain genotypes, the total number of fruits, the number of fruits in the second hand, and the fresh mass of the second hand were also higher for the Maranhão cultivar (Table 5). However, Faria et al. (2010) and Coelho et al. (2013) found higher averages of 150 and 186 fruits, respectively, for total number of fruits in the bunch. Among the Horn plantain genotypes, 88 showed the highest values for all three variables. The reference cultivar D'Angola produced a total number of fruits similar to that found by Faria et al. (2010) and Coelho et al. (2013). The amount of hands and fruits in the bunch is not only a genetic character, but is also affected by other factors, such as cultivation cycle, plant vigor, ecological conditions and cultural management at the time of floral differentiation (Robinson \& Gálan-Saúco, 2010; Soto, 2011), which may have been influenced by the edaphoclimatic conditions of the study region, characterized by a period with less rainfall and low temperatures (Figure 1), as well as by low fertility soils.

Regardless of the production cycles, the fruit fresh mass among the French plantain type was higher

Table 5. Total number of fruits in the bunch, number of fruits in the second hand, and fresh mass of the second hand of French and Horn plantain (Musa spp.) genotypes under the environmental conditions of Ribeira Valley, located in the state of São Paulo, Brazil ${ }^{(1)}$.

\begin{tabular}{|c|c|c|c|c|c|c|c|c|c|}
\hline \multirow[t]{2}{*}{ Genotype } & \multicolumn{3}{|c|}{ Total number of fruits } & \multicolumn{3}{|c|}{ Number of fruits in the $2^{\text {nd }}$ hand } & \multicolumn{3}{|c|}{ Fresh mass of the $2^{\text {nd }}$ hand $(\mathrm{kg})$} \\
\hline & $1^{\text {st }}$ cycle & $2^{\text {nd }}$ cycle & Mean & $1^{\text {st }}$ cycle & $2^{\text {nd }}$ cycle & Mean & $1^{\text {st }}$ cycle & $2^{\text {nd }}$ cycle & Mean \\
\hline & \multicolumn{9}{|c|}{ French plantain } \\
\hline 'Maranhão' & $112 \mathrm{a}$ & $109 \mathrm{a}$ & $111 \mathrm{a}$ & $16.4 \mathrm{a}$ & $16.3 \mathrm{a}$ & $16.3 \mathrm{a}$ & $3.3 \mathrm{a}$ & $3.6 \mathrm{a}$ & $3.4 \mathrm{a}$ \\
\hline 80 & $56 \mathrm{~b}$ & $60 \mathrm{~b}$ & $58 \mathrm{~b}$ & $9.9 \mathrm{~b}$ & $9.8 \mathrm{~b}$ & $9.8 \mathrm{c}$ & $2.8 \mathrm{aA}$ & $1.9 \mathrm{bB}$ & $2.4 \mathrm{~b}$ \\
\hline 79 & $55 \mathrm{~b}$ & $58 \mathrm{~b}$ & $57 \mathrm{~b}$ & $10.0 \mathrm{~b}$ & $10.6 b$ & $10.3 \mathrm{bc}$ & $2.9 \mathrm{a}$ & $2.3 \mathrm{~b}$ & $2.6 \mathrm{~b}$ \\
\hline 84 & $70 \mathrm{~b}$ & $74 \mathrm{~b}$ & $72 b$ & $11.7 \mathrm{~b}$ & $11.3 \mathrm{~b}$ & $11.5 \mathrm{~b}$ & $2.5 \mathrm{a}$ & $2.0 \mathrm{~b}$ & $2.2 \mathrm{~b}$ \\
\hline 82 & $65 \mathrm{~b}$ & $62 b$ & $63 b$ & $11.4 \mathrm{~b}$ & $11.1 \mathrm{~b}$ & $11.3 \mathrm{~b}$ & $2.6 \mathrm{a}$ & $2.6 \mathrm{~b}$ & $2.6 \mathrm{~b}$ \\
\hline 90 & $62 \mathrm{~b}$ & $59 \mathrm{~b}$ & $90 \mathrm{~b}$ & $11.5 \mathrm{~b}$ & $10.4 \mathrm{~b}$ & $10.9 \mathrm{bc}$ & $2.3 \mathrm{aA}$ & $1.7 \mathrm{bB}$ & $2.0 \mathrm{~b}$ \\
\hline Mean & $70 \mathrm{~A}$ & $70 \mathrm{~A}$ & & $11.8 \mathrm{~A}$ & $11.6 \mathrm{~A}$ & & $2.7 \mathrm{~A}$ & $2.3 \mathrm{~B}$ & \\
\hline CV $1(\%)^{(2)}$ & & 17.5 & & & 6.9 & & & 20.4 & \\
\hline \multirow[t]{2}{*}{ CV $2(\%)^{(3)}$} & & 14.5 & & & 7.4 & & & 17.2 & \\
\hline & \multicolumn{9}{|c|}{ Horn plantain } \\
\hline 88 & $33 \mathrm{a}$ & $38 \mathrm{a}$ & $35 \mathrm{a}$ & $7.3 \mathrm{a}$ & $8.3 \mathrm{a}$ & $7.8 \mathrm{a}$ & $2.1 \mathrm{a}$ & $2.4 \mathrm{a}$ & $2.2 \mathrm{a}$ \\
\hline 78 & $30 \mathrm{a}$ & $32 \mathrm{ab}$ & $31 \mathrm{ab}$ & $6.6 \mathrm{ab}$ & $7.0 \mathrm{ab}$ & $6.8 \mathrm{ab}$ & $2.0 \mathrm{a}$ & $2.0 \mathrm{ab}$ & $2.0 \mathrm{ab}$ \\
\hline 'D’ Angola' & $25 \mathrm{ab}$ & $27 \mathrm{bc}$ & $26 \mathrm{bc}$ & $5.8 \mathrm{abc}$ & $6.0 \mathrm{~b}$ & $5.9 \mathrm{bc}$ & $1.9 \mathrm{a}$ & $1.7 \mathrm{~b}$ & $1.8 \mathrm{ab}$ \\
\hline 81 & $20 \mathrm{~b}$ & $24 \mathrm{bc}$ & $22 \mathrm{c}$ & $4.8 \mathrm{c}$ & $5.8 \mathrm{bA}$ & $5.3 \mathrm{~cd}$ & $1.6 \mathrm{a}$ & $1.9 \mathrm{ab}$ & $1.8 \mathrm{ab}$ \\
\hline 83 & $21 \mathrm{~b}$ & $24 \mathrm{bc}$ & $23 \mathrm{c}$ & $5.3 \mathrm{bc}$ & $5.3 \mathrm{~b}$ & $5.3 \mathrm{~cd}$ & $1.8 \mathrm{a}$ & $1.8 \mathrm{~b}$ & $1.8 \mathrm{ab}$ \\
\hline 77 & $19 b$ & $21 \mathrm{c}$ & $20 \mathrm{c}$ & $4.1 \mathrm{c}$ & $5.6 \mathrm{bA}$ & $4.9 \mathrm{~d}$ & $1.5 \mathrm{a}$ & $1.7 \mathrm{~b}$ & $1.6 \mathrm{~b}$ \\
\hline Mean & $25 \mathrm{~B}$ & $28 \mathrm{~A}$ & & $5.6 \mathrm{~B}$ & $6.3 \mathrm{~A}$ & & $1.8 \mathrm{~A}$ & $1.9 \mathrm{ab}$ & \\
\hline CV $1(\%)^{(2)}$ & & 16.8 & & & 10.7 & & & 15.9 & \\
\hline $\operatorname{CV} 2(\%)^{(3)}$ & & 14.6 & & & 13.1 & & & 13.7 & \\
\hline
\end{tabular}

${ }^{(1)}$ Means followed by different letters, lowercase in the columns and uppercase in the lines, differ by Tukey's test, at $5 \%$ probability. ${ }^{(2)}$ Coefficient of variation for genotypes. ${ }^{(3)}$ Coefficient of variation for cycles. 
for genotypes 79, 80, and 82 and cultivar Maranhão (Table 6). However, among the Horn plantain type, the highest average values for both cycles were found for genotypes 77 and 83 . The French plantain genotypes produced a higher number of fruits, but that were smaller than those of the Horn plantain genotypes (Table 6). Silva et al. (2002) concluded that fruit mass is an important variable for the selection of cultivars, especially regarding consumer preferences, but that it should be considered in association with other variables linked to fruit quality, such as fruit length and diameter, for which genotypes 79, 80, and 82 of French plantain stood out, with greater masses related to the greater length and diameter of the fruit, which was not observed for genotypes of the Horn plantain type.

Fruit length was similar for all studied genotypes, with an average of $25 \mathrm{~cm}$ for the French plantain type and $29 \mathrm{~cm}$ for Horn plantain; these values were lower than the ones found by Faria et al. (2010) for cultivars Maranhão and D'Angola. These results show that, although the climate of the study region is subtropical, the produced fruits were larger than those obtained in a tropical and irrigated region in the municipality of Guanambi, in the state of Bahia, considered more favorable for the development of banana trees.

No significant differences were observed for fruit diameter between the French or Horn plantain genotypes and the Maranhão and D'Angola cultivars (Table 6). Faria et al. (2010) reported fruit diameters of $36.7 \mathrm{~mm}$ for cultivar Maranhão and $40.6 \mathrm{~mm}$ for D'Angola, both smaller than those obtained in the present study. Fruit length and diameter are used for classification purposes during commercialization, with better prices mostly for larger fruits according to consumer preferences (Soto, 2011). Fruits of both plantain types reached an ideal length and diameter for the Brazilian and also international markets, with fruits larger than $27 \mathrm{~cm}$ in length and $45 \mathrm{~mm}$ in diameter. Genotypes 79 and 80 of French plantain and 78 and 88 of Horn plantain stood out, whereas genotypes 78 and 88 have the advantage of presenting a lower plant height, which facilitates crop treatment.

Table 6. Fruit fresh mass, length, and diameter of French and Horn plantain (Musa spp.) genotypes under the environmental conditions of Ribeira Valley, located in the state of São Paulo, Brazil ${ }^{(1)}$.

\begin{tabular}{|c|c|c|c|c|c|c|c|c|c|}
\hline \multirow[t]{2}{*}{ Genotype } & \multicolumn{3}{|c|}{ Fruit fresh mass (g) } & \multicolumn{3}{|c|}{ Fruit length $(\mathrm{cm})$} & \multicolumn{3}{|c|}{ Fruit diameter $(\mathrm{mm})$} \\
\hline & $1^{\text {st }}$ cycle & $2^{\text {nd }}$ cycle & Mean & $1^{\text {st }}$ cycle & $2^{\text {nd }}$ cycle & Mean & $1^{\text {st }}$ cycle & $2^{\text {nd }}$ cycle & Mean \\
\hline & \multicolumn{9}{|c|}{ French plantain } \\
\hline 80 & $286 \mathrm{aA}$ & $201 \mathrm{aB}$ & $244 \mathrm{ab}$ & $26 \mathrm{a}$ & $27 \mathrm{a}$ & $27 \mathrm{a}$ & $44 \mathrm{aA}$ & $39 \mathrm{abB}$ & $41 \mathrm{a}$ \\
\hline 79 & $287 \mathrm{aA}$ & $214 \mathrm{aB}$ & $250 \mathrm{a}$ & $27 \mathrm{a}$ & $26 \mathrm{a}$ & $26 \mathrm{a}$ & $43 \mathrm{a}$ & $43 \mathrm{a}$ & $43 a$ \\
\hline 82 & $225 \mathrm{ab}$ & $228 \mathrm{a}$ & $227 \mathrm{ab}$ & $24 \mathrm{a}$ & $24 \mathrm{a}$ & $24 \mathrm{a}$ & $42 \mathrm{a}$ & $42 \mathrm{a}$ & $42 \mathrm{a}$ \\
\hline 84 & $216 a b$ & $173 a$ & $194 \mathrm{ab}$ & $23 \mathrm{a}$ & $23 a$ & $23 \mathrm{a}$ & $41 \mathrm{a}$ & $39 \mathrm{ab}$ & $40 \mathrm{a}$ \\
\hline 90 & $201 b$ & $159 \mathrm{a}$ & $180 \mathrm{~b}$ & $24 a$ & $24 \mathrm{a}$ & $24 \mathrm{a}$ & $40 \mathrm{aA}$ & $36 \mathrm{bB}$ & $38 \mathrm{a}$ \\
\hline 'Maranhão' & $179 \mathrm{~b}$ & $224 \mathrm{a}$ & $201 \mathrm{ab}$ & $25 \mathrm{a}$ & $25 \mathrm{a}$ & $25 \mathrm{a}$ & $38 \mathrm{a}$ & $38 \mathrm{ab}$ & $38 \mathrm{a}$ \\
\hline Mean & $232 \mathrm{~A}$ & $200 \mathrm{~B}$ & & $25 \mathrm{~A}$ & $25 \mathrm{~A}$ & & $41 \mathrm{~A}$ & $40 \mathrm{~B}$ & \\
\hline CV $1(\%)^{(2)}$ & & 18.4 & & & 10.2 & & & 7.4 & \\
\hline \multirow[t]{2}{*}{ CV $2(\%)^{(3)}$} & & 14.9 & & & 11.2 & & & 6.7 & \\
\hline & \multicolumn{9}{|c|}{ Horn plantain } \\
\hline 77 & $378 \mathrm{aA}$ & $305 \mathrm{abB}$ & $342 \mathrm{a}$ & $32 \mathrm{aA}$ & $29 \mathrm{aB}$ & $31 \mathrm{a}$ & $45 \mathrm{a}$ & $45 \mathrm{a}$ & $45 \mathrm{a}$ \\
\hline 83 & $350 \mathrm{a}$ & $344 \mathrm{a}$ & $347 \mathrm{a}$ & $30 \mathrm{ab}$ & $29 \mathrm{a}$ & $30 \mathrm{a}$ & $45 \mathrm{a}$ & $45 \mathrm{a}$ & $45 \mathrm{a}$ \\
\hline 81 & $349 \mathrm{ab}$ & $325 \mathrm{ab}$ & $337 \mathrm{ab}$ & $30 \mathrm{ab}$ & $28 \mathrm{a}$ & $29 a$ & $45 a$ & $46 a$ & $45 \mathrm{a}$ \\
\hline 'D’ Angola' & $333 \mathrm{abA}$ & $277 \mathrm{bB}$ & $305 \mathrm{abc}$ & $30 \mathrm{ab}$ & $29 \mathrm{a}$ & $29 \mathrm{a}$ & $46 a$ & $45 \mathrm{a}$ & $45 \mathrm{a}$ \\
\hline 78 & $301 \mathrm{bc}$ & $293 b$ & $297 \mathrm{bc}$ & $28 \mathrm{~b}$ & $29 \mathrm{a}$ & $28 \mathrm{a}$ & $44 a$ & $44 a$ & $44 a$ \\
\hline 88 & $283 c$ & $295 b$ & $289 \mathrm{c}$ & $27 \mathrm{bB}$ & $30 \mathrm{aA}$ & $28 \mathrm{a}$ & $44 \mathrm{a}$ & $43 \mathrm{a}$ & $43 a$ \\
\hline Mean & $332 \mathrm{~A}$ & $307 \mathrm{~B}$ & & $29 \mathrm{~A}$ & $29 \mathrm{~A}$ & & $45 \mathrm{~A}$ & $45 \mathrm{~A}$ & \\
\hline CV $1(\%)^{(2)}$ & & 8.3 & & & 9.1 & & & 4.5 & \\
\hline CV $2(\%)^{(3)}$ & & 6.7 & & & 5.3 & & & 4.5 & \\
\hline
\end{tabular}

${ }^{(1)}$ Means followed by different letters, lowercase in columns and uppercase in the lines, differ by Tukey's test, at $5 \%$ probability. ${ }^{(2)}$ Coefficient of variation for genotypes. ${ }^{(3)}$ Coefficient of variation for cycles. 


\section{Conclusions}

1. The 78 and 88 Horn plantain (Musa spp.) genotypes show the best vegetative and productive performance, with smaller plants, larger pseudostem diameters, and higher productivity.

2. None of the French plantain genotypes evaluated are able to reach the productive performance of the reference cultivar Maranhão; however, genotypes 79, 80,82 , and 84 present a lower pseudostem height and a shorter total cycle, which could be explored to improve their productive potential.

\section{Acknowledgments}

To Empresa Brasileira de Pesquisa Agropecuária (Embrapa), for financial support.

\section{References}

ALBUQUERQUE, A.F.A. de. Importância socioeconômica e nutricional.In:BORGES,A.L.(Ed.). Cultivodeplátanos(bananeiras tipo Terra). Brasília: Embrapa, 2016. (Embrapa Mandioca e Fruticultura. Sistema de produção, 42). Available at: <https:// www.spo.cnptia.embrapa.br/conteudo?p_p_id=conteudoportlet_ WAR_sistemasdeproducaolf6_1galceportlet\&p_p_ lifecycle $=0 \& p \_p \_s t a t e=$ normal $\& p \_p \_$mode $=v i e w \& p \_p \_$ col_id=column-1\&p_p_col_count $=1 \&$ p_r_p_-76293187_ sistemaProducaoId=8701\&p_r_p_-996514994_topicoId=9902>. Accessed on: May 212021.

AMORIM, E.P.; SANTOS-SEREJO, J.A. dos; AMORIM, V.B.O.; FERREIRA, C.F.; SILVA, S.O. Banana breeding at Embrapa Cassava and Fruits. Acta Horticulturae, v.986, p.171-176, 2013. DOI: https://doi.org/10.17660/ActaHortic.2013.986.18.

AZEVEDO, V.F. de; DONATO, S.L.R.; ARANTES, A. de M.; MAIA, V.M.; SILVA, S. de O. e. Avaliação de bananeiras tipo Prata, de porte alto, no semiárido. Ciência e Agrotecnologia, v.34, p.1372-1380, 2010. DOI: https://doi.org/10.1590/S141370542010000600003 .

BORGES, R. de S.; SILVA, S. de O. e; OLIVEIRA, F.T. de; ROBERTO, S.R. Avaliação de genótipos de bananeira no norte do estado do Paraná. Revista Brasileira de Fruticultura, v.33, p.291-296, 2011. DOI: https://doi.org/10.1590/S010029452011005000034.

CARVALHO, A.C.P.P. de; RODRIGUES, A.A.de J.; SANTOS, E. de O. Produção de mudas micropropagadas de bananeira. Fortaleza: Embrapa Agroindústria Tropical, 2012. 14p. (Embrapa Agroindústria Tropical. Circular técnica, 37).

CAVALCANTE, M. de J.B.; ANDRADE NETO, R. de C.; LEDO, A. da S.; GONDIM, T.M. de S.; CORDEIRO, Z.J.M. Manejo fitotécnico da bananeira, cultivar D' Angola (AAB), visando ao controle da Sigatoka-Negra. Revista Caatinga, v.27, p.201-208, 2014.
CIIAGRO. Centro Integrado de Informações Agrometeorológicas. Available at: <http://www. ciiagro.sp.gov. br>. Accessed on: Apr. 252021.

COELHO, E.F.; OLIVEIRA, R.C. de; PAMPONET, A.J.M. Necessidades hídricas de bananeira tipo Terra em condições de tabuleiros costeiros. Pesquisa Agropecuária Brasileira, v.48, p.1260-1268, 2013. DOI: https://doi.org/10.1590/S0100204X2013000900010.

FARIA, H.C. de; DONATO, S.L.R.; PEREIRA, M.C.T.; SILVA, S. de O. e. Avaliação fitotecnica de bananeiras tipo Terra sob irrigação em condições semi-áridas. Ciência e Agrotecnologia, v.34, p.830-836, 2010. DOI: https://doi.org/10.1590/S141370542010000400006 .

FERREIRA, D.F. Sisvar: a computer statistical analysis system. Ciência e Agrotecnologia, v.35, p.1039-1042, 2011. DOI: https://doi.org/10.1590/S1413-70542011000600001.

FOURÉ, E. Stratégies de lutte contre la cercosporiose noire des bananiers et des plantains provoquée par Mycosphaerella fijiensis Morelet. L'avertissement biologique au Cameroun. Evaluation des possibilités d'amélioration. Fruits, v.43, p.269274, 1988.

GONÇALVES, Z.S. Variabilidade genética entre genótipos de plátanos a partir de dados quantitativos e marcadores ISSR. 2015. 68p. Dissertação (Mestrado) - Universidade Federal Recôncavo da Bahia, Cruz das Almas.

GONZÁlEZ, C.R.; SALINAS, D.G.C.; CASTILLO, J.J.M. Effect of number of functional leaves at flowering on yield of banana Grand Naine (Musa AAA Simmonds). Revista Facultad Nacional de Agronomía Medellín, v.65, p.6585-6591, 2012.

LÉDO, A. da S.; SILVA JUNIOR, J.F. da; LÉDO, C.A. da S.; SILVA, S. de O. e. Avaliação de genótipos de bananeira na região do Baixo São Francisco, Sergipe. Revista Brasileira de Fruticultura, v.30, p.691-695, 2008. DOI: https://doi.org/10.1590/ S0100-29452008000300022.

LIMA, M.B.; SILVA, S. de O. e; JESUS, O.N. de; OLIVEIRA, W.S.J. de; GARRIDO, M. da S.; AZEVEDO, R.L. Avaliação de cultivares e híbridos de bananeira no Recôncavo Baiano. Ciência e Agrotecnologia, v.29, p.515-520, 2005. DOI: https://doi.org/10.1590/S1413-70542005000300002.

LINS, L.C.R. de; FANCELLI, M.; RITZINGER, C.H.S.P.; COELHO FILHO, M.A.; LEDO, C.A. da S. Torta de mamona no controle da broca-do-rizoma (Cosmopolites sordidus) em bananeira-Terra. Revista Brasileira de Fruticultura, v.35, p.493-499, 2013. DOI: https://doi.org/10.1590/S010029452013000200019.

MORAES, W. da S.; SILVA, S.H.M.-G. da; FUKUDA, E.; SILVA, C.M. da. Técnica de monitoramento da Sigatoka-negra na cultura da banana. Pesquisa \& Tecnologia, v.8, 2011.

MOREIRA, R.S. Banana: teoria e prática de cultivo. 2.ed. Campinas: Fundação Cargill, 1999. 1 CD ROM.

NOMURA, E.S.; DAMATTO JUNIOR, E.R.; FUZITANI, E.J.; AMORIM, E.P.; SILVA, S. de O. e. Avaliação agronômica de genótipos de bananeiras em condições subtropicais, Vale do Ribeira, São Paulo - Brasil. Revista Brasileira de Fruticultura, 
v.35, p.112-122, 2013. DOI: https://doi.org/10.1590/S010029452013000100014.

RAIJ, B. van; CANTARELLA, H.; QUAGGIO, J.A.; FURLANI, A.M.C. (Ed.). Recomendações de adubação e calagem para o Estado de São Paulo. 2.ed. rev. e atual. Campinas: IAC, 1997. 285p. (IAC. Boletim técnico, 100).

ROBINSON, J.C.; GALÁN SAÚCO, V. Bananas y plantains. $2^{\text {nd }}$ ed. Wallington: Cabi, 2010. 321p. DOI: https://doi.org/10.1079/97 81845936587.0000 .

RODRIGUES FILHO, V.A.; DONATO, S.L.R.; ARANTES, A.M.; COELHO FILHO, M.A.; LIMA, M.B. Growth, yield and gas exchanges of 'D'Angola' plantain under different plant densities. Revista Brasileira de Engenharia Agrícola e Ambiental, v.24, p.490-496, 2020. DOI: https://doi.org/10.1590/1807-1929/ agriambi.v24n7p490-496.

SILVA, S. de O. e; FLORES, J.C. de O.; LIMA NETO, F.P. Avaliação de cultivares e híbridos de bananeira em quatro ciclos de produção. Pesquisa Agropecuária Brasileira, v.37, p.1567-1574, 2002. DOI: https://doi.org/10.1590/S0100-204X2002001100007.
SILVA, S. de O. e; PIRES, E.T.; PESTANA, R.K.N.; ALVES, J. da S.; SILVEIRA, D. de C. Avaliação de clones de banana Cavendish. Ciência e Agrotecnologia, v.30, p.832-837, 2006. DOI: https://doi.org/10.1590/S1413-70542006000500002.

SOTO, M. Situación y avances tecnologicos en la producción bananera mundial. Revista Brasileira de Fruticultura, v.33, p.13-28, 2011. DOI: https://doi.org/10.1590/S010029452011000500004.

TEIXEIRA, L.A.J.; NOMURA, E.S.; DAMATTO JUNIOR, E.R.; FUZITANI, E.J. Banana. In: AGUIAR, A.T. da E.; GONÇALVES, C.; PATERNIANI, M.E.A.G.Z.; TUCCI, M.L.S.; CASTRO, C.E.F. de (Ed.). Instruções agrícolas para as principais culturas econômicas. 7.ed. rev. e atual. Campinas: Instituto Agronômico, 2014. p.46-51. (IAC. Boletim técnico, 200).

TRIPATHI, L.; BABIRYE, A.; RODERICK, H.; TRIPATHI, J.N.; CHANGA, C.; URWIN, P.E.; TUSHEMEREIRWE, W.K.; COYNE, D.; ATKINSON, H.J. Field resistance of transgenic plantain to nematodes has potential for future African food security. Scientific Reports, v.5, art.8127, 2015. DOI: https://doi.org/10.1038/srep08127. 